\title{
NOTES
}

\section{FTC SUBSTANTIVE RULEMAKING AUTHORITY}

Federal administrative agencies generally enforce statutory mandates which are drawn in broad and ill-defined terms. Consequently, one of the central tasks of such agencies is to formulate policies which serve to elaborate and clarify the substantive law governing the conduct of regulated parties. Typically, such policies are developed either pursuant to rulemaking proceedings or incident to agency adjudications. ${ }^{1}$

1. See NLRB v. Wyman-Gordon Co., 394 U.S. 759, 765-66, 770-71 (1969); SEC v. Chenery Corp., 332 U.S. 194, 202-03 (1947). Policy is made incident to adjudication to the extent that clear, but broad, doctrines are announced and the principle of stare decisis is employed to create precedents. Legislative rulemaking produces a specific policy statement covering all cases within its scope arising in the future. Of course, the extent of an agency's power to employ each of these procedures is determined by the agency's enabling statute. See Fuchs, Agency Development of Policy Through Rule-Making, 59 Nw. U.L. REv. 781, 796-97 (1965); Shapiro, The Choice of Rulemaking or Adjudication in the Development of Administrative Policy, 78 HARV. L. Rev. 921,960 (1965).

HEREAFTER THE FOLLOWING CITATIONS WILL BE USED IN THIS NOTE:

Statement of Basis and Purpose of the Trade Regulation Rule for the Prevention of Unfair or Deceptive Advertising of Cigarettes in Relation to the Health Hazards of Smoking, 29 Fed. Reg. 8325 (1964) [heremafter cited as 1964 Statement of Basis];

Burrus \& Teter, Antitrust: Rulemaking v. Adjudication in the FTC, 54 GEo. L.J. 1106 (1966) [heremafter cited as Burrus \& Teter];

Fuchs, Agency Development of Policy Through Rule-Making, 59 Nw. U.L. REv. 781 (1965) [hereinafter cited as Fuclis];

Robinson, The Making of Administrative Policy: Another Look at Rulemaking and Adjudication and Administrative Procedure Reform, 118 U. PA. L. Rev. 485 (1970) [heremafter cited as Robinson];

Shapiro, The Choice of Rulemaking or Adjudication in the Development of Administrative Policy, 78 HARv. L. REv. 921 (1965) [hereinafter cited as Shapiro];

Wegman, Cigarettes and Health: A Legal Analysis, 51 CORNELL L.Q. 678 (1966) [hereinafter cited as Wegman];

Weston, Deceptive Advertising and the Federal Trade Commission: Decline of Caveat Emptor, 24 FED. B.J. 548 (1964) [heremafter cited as Weston];

Note, The Use of Rulemaking to Deny Adjudications Apparently Required by Statute, 54 Iowa L. REv. 1086 (1969) [hereinafter cited as Rulemaking to Deny Adjudications];

Note, FTC Substantive Rulemaking: An Evaluation of Past Practices and Proposed Legislation, 48 N.Y.U.L. REv. 135 (1973) [hereinafter cited as FTC Substantive Rulemaking]. 
For nearly fifty years after its creation in 1914, the Federal Trade Commission (FTC) relied exclusively upon agency adjudications as the means of authoritatively defining and enforcing the Federal Trade Commission Act's (FTCA) ${ }^{2}$ broad prohibitions against "unfair methods of competition" and "unfair or deceptive" trade practices. ${ }^{3}$ As a result, the scope of these standards of conduct remained uncertain, being subject to the necessity of evolution by case precedent, ${ }^{4}$ and FTC enforcement was hindered by the delays inherent in litigation, especially where industry-wide violations required repeated hearings on the same, or similar, issues. ${ }^{5}$ In 1962 , in order to establish a more efficacious

2. 15 U.S.C. $\$ \S 41-58$ (1970) (originally enacted as Act of Sept. 26, 1914, ch. 311, 38 Stat. 717).

3. 15 U.S.C. $\$ 45(\mathrm{a})(1)$ (1970). The 1914 Act limited the prohibition to "unfair methods of competition." Act of Sept. 26, 1914, ch. 311, § 5, 38 Stat. 717. The scope of the standard of illegality was expanded in 1938 by the Wheeler-Lea Amendment to cover "unfair or deceptive acts or practices" as well. Act of March 21, 1938, ch. $49, \S 5,52$ Stat. 111 .

4. In an FTC adjudication, see note 15 infra and accompanying text, the Commission must determine (1) whether the respondent is actually engaged in the conduct cited in the FTC complaint and (2) whether such conduct constitutes unfair competition or a deceptive practice. It is the latter inquiry which results in the evolution of agency policy.

Because of the unpredictable manner in which violations, and hence policy issues, arise, the Commission has long found it necessary to employ several procedures aimed at supplementing the adjudication process and more effectively providing regulated parties with guidance as to Commission policy. Since 1919, the Commission has issued Trade Practice Conference Rules, developed pursuant to the joint efforts of industry and the Commission. (These rules as currently in force are reprinted at $4 \mathrm{CCH}$ TRADE REG. REP. IfT $41,003-41,227$.) The purpose of such rules is to obtain uniform voluntary compliance with the FTCA by making clear the Commission's policy concerning certain trade practices. Note, Voluntary Compliance: An Adjunct to Mandatory Processes, 38 IND. L. REv. 377, 385-88 (1963); Weston 566-67. But the rules are without legal force. An industry member engaging in a trade practice contrary to a Trade Practice Rule would not automatically be in violation of the FTCA; rather a complaint alleging the trade practice to be in violation of the standard of illegality set forth in the Act would be issued and a determination of the statutory validity of the challenged conduct, apart from its conformity to any applicable Trade Practice Rule, would become necessary in the subsequent adjudication. 16 C.F.R. $\$ \S 1.5-.6,17.1,17.3-.4$ (1973). See Auerbach, The Federal Trade Commission: Internal Organization and Procedure, 48 MnN. L. Rev. 383, 452 (1964); Shapiro 964; Weston 567; Note, supra at 388. But cf. Prima Prods., Inc. v. FTC, 209 F.2d 405, 408 (2d Cir. 1954).

Likewise, the Commission has issued Guides, interpretations of the lavs administered by the Commission, since 1955, 16 C.F.R. $\$ \$ 1.5-.6,17.1$ (a) (1973), and Advisory Opinions, since 1962, id. \$\$ 1.1-.4. See Auerbacl, supra, at 452-55; Weston 567; Note, supra at 394-95, 404. However, these supplemental procedures have not served to eliminate uncertainty concerning agency policy and the probable legality of certain trade practices. See REPORT OF THE ABA COMMISSION to STUdY tHe FEDERAL TRADE COMMISSION 11 (1969); Shapiro 967.

5. See E. Cox, R. Fellmeth \& J. Schulz, The Nader Report on the Federal TRADE COMMISSION 31, 71-87 (1969); Auerbach, supra note 4, at 449; Weginan 740; 
procedure for dealing with violations of the FTCA, the Commission amended its procedures to provide for the promulgation of Trade Regulation Rules which have the force of substantive law. ${ }^{6}$ Under this enforcement procedure the scope of inquiry in FTC adjudications to which a Trade Regulation Rule applies would be narrowed to the question of whether a respondent's conduct violated the relevant rule, thus relieving the Commission of the evidentiary burden of establishing, in each of a number of cases, that a particular trade practice violates the broad standards contaimed in the FTCA. ${ }^{7}$ Pursuant to this new procedure

Weston, 561; Note, The Federal Trade Commission and Reform of the Administrative Process, 62 Colum. L. REv. 671, 697 (1962). Moreover, individual adjudications have proven lengthy as well as repetitious. An FTC adjudication involving a single violator may extend (from the issuance of a coinplaint to the issuance of a cease and desist order to ultimate appellate court review) for a period froin three to five years. See also Report of tHe ABA Commission, supra note 4, at 28-32; Simon, The Case Against the Federal Trade Commission, 19 U. CHr. L. Rev. 297, 334 n.144 (1952); Weston 561; Note, supra, at 697 n.192. A glaring example of such delay is Carter Products, Inc. v. FTC, 268 F.2d 461 (9th Cir.), cert. denied, 361 U.S. 884 (1959) (proceedings extending over sixteen years).

6. 27 Fed. Reg. 4609 (1962); 16 C.F.R. $\$ \$ 1.11-.16$ (1973).

Trade Regulation Rules specify certain trade practices as falling within the FTCA's broad prohibitions against unfair trade practices. Under its procedures the Commission may utilize a rule to resolve any issue in a cease and desist order adjudication to which it is relevant. 16 C.F.R. $\$ 1.12$ (c) (1973); see 1964 Statement of Basis 8371. The Commission has further indicated that in agency adjudications in which a Trade Regulation Rule is apphied, respondents would be precluded from introducing evidence for the purpose of rebutting either the propositions of law embodied in the rule or the underlying factual determinations upon which the rule is based. Id. at 8371-72. Initially, the FTC denied that Trade Regulation Rules had the force and effect of governing law. Id. at 8369 n.143. However, the purpose of the rulemaking program would be undermined if the rules were not consistently treated as being controlling in subsequent adjudications and, thus, binding upon regulated parties. See Shapiro 966; Note, Federal Trade Commission-Lack of Authority to Promulgate Traale Regulation Rules Having the Effect of Law, 14 B.C. IND. \& CoM. L. REv. 368, 37782 (1972).

7. The expectation of the Commission is that such use of rulemaking would tend to encourage voluntary complance by affected business entities. Moreover, where a subsequent adjudication is required, the "streamlined" nature of the proceedings would significantly reduce the burden of preventing industry-wide violations. 1964 Statement of Basis 8371; see Note, supra note 6, at 378-80. See note 6 supra and accompanying text.

Since 1962 the FTC has issued inore than twenty Trade Regulation Rules. The Commission's initial rulemaking efforts were of a modest nature dealing with relatively simple problems which generated hittle or no controversy. See, e.g., 16 C.F.R. $\$ 400.1$ (1973) (deceptive labeling of sleeping bags); id. $\$ 404.3$ (deceptive labeling of tablecloths). On three separate occasions more aggressive rulemaking by the Commission was superseded by congressional action. Sections 132-34 of the Truth in Lending Act, 15 U.S.C. \$\$ 1642-44 (1970), preempted a proposed rule aimed at regulating the unsolicited mailing of credit cards, 35 Fed. Reg. 4614 (1970), rescinded, 36 Fed. Reg. 45 (1971). The Postal Reorganization Act, 39 U.S.C. $\$ 3009$ (1970), rendered unnecessary the proposed rule concerning the shipinent of unordered merchandise, 35 Fed. 
the FTC, in 1971, issued a Trade Regulation Rule which specifies that the failure of gasoline refiners or distributors to post the minimum octane numbers of gasoline on dispensing punps is an unfair or deceptive trade practice. ${ }^{8}$ Two trade associations and thirty-four gasoline refining companies brought suit for declaratory and injunctive relief, in which they challenged, inter alia, the Commission's statutory authority to issue Trade Regulation Rules. ${ }^{9}$

Reg. 10,116, public hearing cancelled, id. at 14,328 (1970). Perhaps the most controversial Trade Regulation Rule was that which would have required cigarette manufacturers to place on cigarette packages a label disclosing that "cigarette smoking is dangerous to health and may cause death from cancer and other diseases." 29 Fed. Reg. 8324, 8325 (1964). It was preempted by the Federal Cigarette Labeling and Advertising Act, 15 U.S.C. $\$ \S 1331-40$ (1970). Only recently has the Commission begun to make more ambitious use of its rulemaking program. See 16 C.F.R. $\$ 419$ (1973) (regulation of games of chance in the food retailing and gasoline industries); 36 Fed. Reg. 21,607, 22,187 (1971) (proposed rule requiring disclosure of contract provisions in franchise agreements); 37 Fed. Reg. 22,934 (1972), 38 Fed. Reg. 30,105, 33,766 (1973) (proposed rule permitting a "cooling off" period after which a consumer may cancel a "door-to-door" sale); $i d$. at 892 (proposed rule preserving consumers' claims and defenses against subsequent holders of a consumer note). A current list of all final and proposed Trade Regulation Rules is reprinted at 4 CCH TRADE REG. REP. का 38,011-32.

8. 16 C.F.R. $\S 422.1$ (1973).

In establishing the octane rating rule the Commission adhered to the procedural requirements set forth in section 4 of the Administrative Procedure Act (APA), 5 U.S.C. $\$ 553(1970)$, as well as its own procedural rules. 16 C.F.R. \& 1.16 (1973). On JuJy 30,1969 , the FTC published a proposed octane rating rule, the body of which included the posting requirement. The proposed Rule was accompanied by notice of the rulemaking proceedings, which were to be open to participation by interested parties. 34 Fed. Reg. 12,449 (1969). Hearings having been held, and data submitted by participants having been entered into the public record, the Commission issued, on December 30, 1970, a revised Octane Posting Rule. The Rule was to become effective six months thereafter. 36 Fed. Reg. 354 (1971). A question arose concerning the rehability of the method to be used for determining the octane rating and the Commission reopened the record to inquire into the soundness of the inethod prescribed. Id. at 7309. Subsequently, the Commission published a modified Octane Posting Rule which would require the posting of average or "minimum" laboratory octane numbers on dispensing pumps. Id. at 16,120 . The final version of the Rule was published on December 16, 1971, to become effective on March 15, 1972. Id. at 23,871. The Rule was accompanied by a Statement of Basis and Purpose which gave as the basis for the Rule the Commission's conclusion that the absence of posted octane ratings on dispensing pumps adversely influences the consumer's ability to select the proper gasoline for his automobile. Id. at 23,880.

9. National Petroleuin Refiners Ass'n v. FTC, 482 F.2d 672, 674 n.2 (D.C. Cir. 1973), cert. denied, 42 U.S.L.W. 3485 (U.S. Feb. 26, 1974). Prior to $\mathrm{Na*}$ tional Petroleum Refiners, two previous cases in which the FTC's rulemaking authority had been challenged were dismissed on "ripeness" grounds. Bristol-Myers Co. v. FTC, 424 F.2d 935 (D.C. Cir.), cert. denied, 400 U.S. 824 (1970); Lever Bros. Co. v. FTC, 325 F. Supp. 371 (D. Me. 1971). As of 1973, the Commission had not made use of any Trade Regulation Rule in an FTC adjndication. See FTC Substantive Rulemaking 143-47, 159. 
The district court, ruling in favor of the plaintiffs' motion for summary judgement, held that the Commission's rulemaking authority under the FTCA was limited to procedural and housekeeping matters and therefore found the challenged Trade Regulation Rule invalid. ${ }^{10}$ On appeal, the Court of Appeals for the District of Columbia Circuit in National Petroleum Refiners Association v. FTC, ${ }^{11}$ reversed, holding that the FTC's rulemaking power is sufficiently broad to encompass substantive, as well as procedural rulemaking. ${ }^{12}$

This Note will discuss the question of whether the FTCA authorizes substantive rulemaking by the FTC. After initially examining the statutory framework of the FTCA, it then will discuss judicial interpretations of the rulemaking authority of other federal regulatory agencies. Finally, it will compare the contrasting opinions of the district court and the court of appeals in the National Petroleum Refiners litigation and assess the inpact of the latter decision upon the FTC.

\section{STATUTORY FRAMEWORK}

\section{Section $6(g)$ of the FTCA}

The statutory provisions scrutinized in National Petroleum Refiners are contained in sections 5 and 6 of the FTCA. ${ }^{13}$ In addition to the broad substantive mandate of the FTC to prevent "[u]nfair methods of coinpetition im commerce and unfair or deceptive acts or practices in commerce," 14 section 5 sets forth a comprehensive enforcement inechanism by which the Commission is directed to proceed agaimst suspected violators by issuing a complaint, holding a hearing, making findings of fact, and issuing a cease and desist order if a violation is found to have occurred. ${ }^{15}$ There is, however, no reference to rulemaking among these enforcement provisions. The only rule-

10. National Petroleum Refiners Ass'n v. FTC, 340 F. Supp. 1343, 1345-46 (D.D.C. 1972), rev'd, 482 F.2d 672 (D.C. Cir. 1973), cert. denied, 42 U.S.L.W. 3485 (U.S. Feb. 26, 1974). The district court's decision is noted in 14 B.C. IND. \& CoM. L. Rev. 368 (1972); 1973 DuKE L.J. 336, in 1972 Developments; 18 S. DaK. L. REV. 243 (1973); and 21 U. KAN. L. REv. 198 (1973).

11. 482 F.2d 672 (D.C. Cir. 1973), cert. denied, 42 U.S.L.W. 3485 (U.S. Feb. 26, 1974). For a discussion of the court of appeals' decision, see Note, Substantive Rulemaking and the FTC, 41 FORDHAM L. REv. 178 (1973).

12. 482 F.2d at $685-86,693$.

13. 15 U.S.C. $\S \S 45,46(1970)$.

14. Id. $\S 45(\mathrm{a})(1),(6)$.

15. Id. $\S 45(\mathrm{~b})$. Additional provisions in section 5 establish methods of service of process, id. $\S 45$ (f), a grant of jurisdiction and procedures for obtaining judicial review of cease and desist orders by courts of appeals, id. $\$ 45(\mathrm{c})$-(e), (i), criteria for determining the finatity of cease and desist orders, id. $\S 45(\mathrm{~g})$, and penalties forr failure to observe such orders once final, $i d . \S 45(l)$. 
making provision in the FTCA is section $6(\mathrm{~g})$ which empowers the FTC to "classify corporations and to make rules and regulations for the purpose of carrying out the provisions of [the FTCA]."16 In contrast to the scheme of section 5, however, the seven other provisions of section 6 , as well as the first clause of section $6(\mathrm{~g})$ itself, relate specifically to the Commission's functions of gathering and reporting data concerning business practices. ${ }^{17}$ Moreover, it is significant that the FTCA contains no provisions, comparable to the detailed specifications applicable to cease and desist order adjudications, ${ }^{18}$ which outline procedural safeguards for rulemaking or which estabhish penalties for violation of section $6(\mathrm{~g})$ rules; nor does the statute provide for judicial review of such rules. ${ }^{19}$ Thus, it has been argued that, in hight of the central importance of substantive rulemaking to both the FTC and regulated parties, the inconspicuous placement of the rulemaking provision ainong the investigatory provisions of section 6 militates against reading section $6(\mathrm{~g})$, despite its broad language, to permit substantive rulemaking. ${ }^{20}$

\section{The Legislative History of the FTCA}

This argument is buttressed by a number of elements of the legislative history of the FTCA which tend to undermine the Commission's claim to substantive rulemaking authority. ${ }^{21}$ Included in the House version of the $\mathrm{Act}^{22}$ was a rulemaking provision nearly identical in

16. $I d . \S 46(\mathrm{~g})$ (emphasis added).

17. Id. $\$ 46(\mathrm{a})-(\mathrm{f}),(\mathrm{h})$. These provisions empower the FTC to (a) investigate corporations; (b) require corporations to submit reports concerning their business practices; (c) investigate possible failures to comply with Department of Justice antitrust decrees; (d) investigate and report facts concerning alleged antitrust violations to the President and Congress upon request; (e) investigate and recommend adjustments in busmess practices to comply with the law; (f) make reports to the public and Congress; and (h) investigate foreign trade conditions as they affect the United States.

18. See note 15 supra and accompanying text.

19. Although it post-dates the FTCA by more than 30 years, the APA and its procedural and judicial review provisions applicable to rulemaking apply to FTC rulemaking, thus compensating for the absence of such provisions in the FTCA itself. See Fuchs 797-99; 21 U. KaN. L. REv. 198, 209 (1973).

20. See Burrus \& Teter 1121-23, 1125-27; Weston 569-70; Note, The FTC's Claim of Substantive Rule-making Power: A Study in Opposition, 41 GEO. WASH. L. REv. 330, 334-35 (1972). But see K. Davis $\$ \S 5.04,6.18$ (Supp. 1970); Wegman 741-51.

21. For extensive reviews of the legislative history of the FTCA, see National Petroleum Refiners Ass'n v. FTC, 482 F.2d 672, 685-89, 698-709 (Appendix) (D.C. Cir. 1973); G. Henderson, The Federal Trade Commission: A Study in AdministraTIVB LAW AND PROCEDURE, 1-48 (1927); Baker \& Baum, Section 5 of the Federal Trade Commission Act: A Continuing Process of Redefinition, 7 VIII. L. REV. 517, 520-42 (1962); Note, supra note 20 , at 332, 335-39.

22. H.R. 15613, 63d Cong., 2d Sess. (1914). 
terms to section $6(\mathrm{~g}) .^{23}$ However, the bill did not confer any independent enforcement authority upon the proposed Commission; ${ }^{24}$ thus, the rulemaking provision was limited by the entire scheme of the bill to enabling the Commission to implement the non-substantive tasks of investigation and recommendation which were to be its primary responsibilities. Although several attempts were made to amend the House bill in order to vest the Commission with the authority to make "rules and regulations" in aid of enforcing a substantive mandate, none were successful. ${ }^{25}$ In contrast, the Senate version, ${ }^{26}$ written as a substitute for the previously passed House bill, gave the Commission power to enforce a broad statutory standard of illegality, ${ }^{27}$ yet contained no rulemaking provision whatever. ${ }^{28}$ When the two bills came before the Conference Committee, the only rulemaking provision under consideration was that contained in the House bill. Consequently, it was only upon the Conference Committee's synthesis of the House and Senate bills that the FTCA's substantive provisions and the rulemaking provision were united in a single piece of legislation. Thereafter no reference was made in the enacting Congress to the possible relationship between section $6(\mathrm{~g})$ and section $5 .^{29}$ In fact, the only discussion

23. Section 8 of the House bill provided: "That the commission may . . . make rules and regulations ... . for the purpose of carrying out the provisions of this Act." Comparative Print of Federal Trade Commission Bill, S. Doc. No. 573, 63d Cong., 2d Sess. 15 (1914) (reprint of House, Senate, and Conference Committee bills).

24. The bill contained no substantive prohibitions or any declarations of illegality, nor did it provide for any enforcement mechanisn. H.R. 15613, 63d Cong., 2d Sess. (1914). The bill would liave limited the functions of the Commission to those of an investigatory and advisory nature. See H. REP. No. 533, 63d Cong., 2d Sess. 3-7 (1914); Baker \& Baum, supra note 21, at 525-26.

25. See H.R. Rep. No. 533, 63d Cong., 2d Sess., Pt. 3, Appendix 19, 21 (1914) (Representative Lafferty's mimority proposal, made in committee); 51 CoNG. Rzc. 9047, 9050 (1914) (Representative Morgan's amendment); $i d$. at 9056 (Representative Dillon's ainendment).

26. S. 4160, 63d Cong., 2d Sess. (1914).

27. The substantive standard of illegality-a prohibition of "unfair competition"was deliberately left broad and unspecific so to prevent ingenious monopolists from inventing new forms of business practices detrimental to conpetition which would be beyond the foresight of the framers. Id. $\$ 5$; Comparative Print, supra note 23, at 7 . 9. See also S. Rep. No. 597, 63d Cong., 2d Sess. 8 (1914). Like the House bill, the Senate version included provisions which granted the Conumission investigatory and advisory functions, and power to aid the courts in shaping decrees pursuant to suits under the antitrust laws. See id. at 11-13. at 12 .

28. S. 4160 , 63d Cong., $2 \mathrm{~d}$ Sess. (1914). See Comparative Print, supra note 23,

29. Neither the Conference Committee Report, the Conference Committee's Coinparative Print (which diagrams the changes made in conference), nor the final floor debates focused upon the intended scope of section $6(\mathrm{~g})$. See H.R. CoNF. REP. No. 1142, 63d Cong., 2d Sess. 11, 18 (1914); Comparative Print, supra note 23, at 12, 15; 51 CoNG. ReC. 14,796-802 (Senate), 14,819-943 (House) (1914). 
of the scope of the Commission's powers following the Conference Committee's synthesis occurred in the House, which was considering the substantive provisions for the first time. In those debates the House members of the Conference Committee asserted that the Commission would "have no power to prescribe the methods of competition .... in [the] future" and that "it will not be exercising power of a legislative nature."30

It is thus apparent that the authority to make substantive rules was not deliberately granted to the FTC. Those who have contested the FTC's assertion of substantive rulemaking authority have pointed to these origins of the FTCA's rulemaking provision and the remarks made in the final debates in the House as indications that Congress did not intend to grant such authority to the Commission. ${ }^{31}$ However, it is a fact that the framers of the FTCA did include in the Act a rulemaking provision which is not expressly restricted to any particular matters. ${ }^{32}$ Further, those instrumental in the passage of the bill expressed their anticipation that the FTC would make strong and affirmative use of its power to condemn violations of the FTCA. ${ }^{33}$

\section{Post-Enactment History}

Under generally accepted principles of statutory construction, an agency's long-standing interpretation of its statutory powers, developed contemporaneously with the agency's creation, is usually given much deference by courts when the nature of these powers is in question. ${ }^{34}$

30. 51 CoNG. REc. 14,932 (1914) (remarks of Representative Covington); see id. at 14,938 (remarks of Representative Stevens). But see National Petroleum Refiners Ass'n v. FTC, 482 F.2d 672, 706-09 (D.C. Cir. 1973); Wegman 742-45 (indicating that the context of such remarks renders dubious any conclusion that they were specifically aimed at foreclosing substantive rulemaking).

31. See Burrus \& Teter 11, 22-23; Shapiro 960; Weston 570-71.

32. See notes 16,29 supra and accompanying text.

33. See 51 CoNG. REc. 14,927-28 (1914) (remarks of Representative Covington); S. ReP. No. 597, supra note 27, at 10; H.R. CoNr. ReP. No. 1142, 63d Cong., 2d Sess. 19 (1914); Wegman 744.

It should also be noted that the trade commission bill was, to a large extent, the result of dissatisfaction with the delay and meffectiveness of the enforcement of the antitrust laws through traditional hitigation in the courts. G. HENDERSON, supra note 21 , at 17-19; see 51 CoNG. Rec. 8974 (1914) (remarks of Representative Murdock); id. at 9057 (remarks of Representative Dillon).

34. Udall v. Tallman, 380 U.S. 1, 16 (1965); 2A J. SUTHerLaND, STATUTES AND STATUTORY CONSTRUCTION $\$ 49.04$ (Sands 4th rev. ed. 1973). But see note 103 infra. However, it has been noted that there may be non-statutory reasons for an agency's reluctance to utilize rulemaking, even though such authority is conferred by the statute-e.g., budgetary constraints, the need to devote attention to other concerns, or administrative inertia. See Umited States v. Morton Salt Co., 338 U.S. 632, 647-48 (1950); Shapiro 942-58. See also A. Downs, INSIDE BUREAUCRACY 167-74 (1967). 
Thus it is significant that the FTC did not assert its authority to issue substantive rules under the FTCA until $1962,{ }^{35}$ and that prior to that time, the Commission itself had intermittently indicated that the FTCA did not confer such power upon the agency. ${ }^{36}$ Even inore importantly, Congress has on several occasions expressly conferred upon the Commission specific statutory authority to make substantive rules with which to regulate the trade practices of particular industries. ${ }^{37}$ It

35. See note 6 supra and accompanying text.

36. The FTC, in its Annual Reports, has described its enforcement proceedings in terms suggesting that adjudication is the sole method of defining the standard of illegality, see, e.g., 1951 FTC ANN. REP. 16-18, and has indicated that its rulemaking authority is limited to setting forth standards of voluntary comphance, see, e.g., 1948 FTC ANN. REP. 2; 1949 FTC ANN. REP. 2. Representatives from the FTC have mentioned the Commission's lack of substantive rulemaking authority in testimony before congressional committees. Hearings on S. 1666 and S. 1663 (in part) Before the Subcomm. on Administrative Practice and Procedure of the Comm. on the Judiciary, "Freedom of Information," 88th Cong., 1st Sess. 169-70 (1963) (remarks of Paul Rand Dixon, former Chairman of the FTC); Hearings on S. 387 Before the Subcomm. on Antitrust and Monopoly of the Comm. on the Judiciary, "Packaging and Labeling," 88th Cong., 1st Sess. 281 (1963) (remarks of Paul Rand Dixon); see Hearings on S. 986 Before the Consumer Subcomm. of the Comm. on Commerce, "Consumer Products Warranties," 92d Cong., 1st Sess. 37 (1971) (remarks of Miles W. Kirkpatrick, former Chairman of the FTC); Hearings on S. 2246, S. 3092 \& S. 3201 Before the Consumer Subcomm. of the Comm. on Commerce, 91st Cong., 1st and 2d Sess. 9 (1970) (remarks of Caspar W. Weinberger, former Chairman of the FTC). But cf. United States v. Southwestern Cable Co., 392 U.S. 157, 169-70 (1968) (the Supreme Court rejected the contention that requests by the FCC for additional legislation specifically authorizing the regulation of Community Antenna Television precluded an interpretation of the Federal Communications Act of 1934 that the FCC already had such regulatory authority).

Similar characterizations of the FTC's rulemaking authority have emerged by way of dicta in a number of Supreme Court decisions. In Hunphrey's Executor v. Umited States, 295 U.S. 602 (1935), the Supreme Court was faced with the question of the President's power to remove a Federal Trade Commissioner. The opinion, written by Justice Sutherland, who was a member of the Senate when the FTCA was enacted, reviewed the powers conferred upon the FTC by sections 1, 5, 6, and 7 of the Act. The view expressed in the opimion was that the substantive provisions were to be defined in section $5(\mathrm{~b})$ adjudications and that section 6 was concerned with agency investigations. Id. at 620-21. See also Pan Am. World Airways v. United States, 371 U.S. 296, 307-08 (1963); A.L.A. Schechter Poultry Corp. v. United States, 295 U.S. 495, 533 (1935); FTC v. Raladam Co., 283 U.S. 643, 648 (1931); FTC v. Gratz, 253 U.S. 421, 435-37 (1920) (cases indicating that the elaboration of the standard of illegality is to be brought about by a "gradual process of judicial inclusion and exclusion," FTC v. Raladam Co., supra at 648). But see Atlantic Refining Co. v. FTC, 381 U.S. 357, 390-91 (1965): "The Commission has the general power to choose to proceed . . . through either rulemaking or the process of case-by-case adjudication" (Goldberg, J., dissenting).

37. See Wool Products Labeling Act of 1939, 15 U.S.C. $\$ \$ 68-68 \mathrm{j}, 68 \mathrm{~d}$ (a) (1970); Fur Products Labeling Act, id. \$\$ 69-69j, 69f(a)(2)(B); Textile Products Identification Act, id. $\$ \S 70-70 \mathrm{k}, 70 \mathrm{e}(\mathrm{c})$; Flammable Fabrics Act, id. $\$ \$ 1191-2000$, 1194(c); Fair Packaging and Labeling Act, id. $\S \S 1451-61,1454$. The rulemaking pro- 
has been suggested that these limited grants of substantive rulemaking authority reflect a congressional interpretation that the FTC lacks such power generally. ${ }^{38}$

\section{EXPANSIVE INTERPRETATIONS OF AgENCY RULEMAKING POWERS}

Although the cumulative weight of the legislative ${ }^{38}$ and post-enactment $^{40}$ histories of the FTCA and the placement of section $6(\mathrm{~g})$ among the Act's investigative and housekeeping provisions rather than with the statute's substantive provisions ${ }^{41}$ tends to undercut the FTC's claim to substantive rulemaking authority, a number of decisions reveal a judicial willingness to allow federal regulatory agencies, and the FTC in particular, substantial procedural flexibility in pursuing their respective statutory mandates. Prior to the National Petroleum Refiners litigation, no court had squarely faced the question of whether the FTCA confers substantive rulemaking authority on the Commission. ${ }^{42}$ However, in United States $v$. Morton Salt Co. ${ }^{43}$ the Supreme Court observed that "[t]he [FTCA] is one of several [statutes] in which Congress, to make its policy effective, has relied upon the initiative of administrative officials and the flexiblity of the administrative process," 4 and upheld the FTC's authority to employ a "section 6" power

vision in the Flammable Fabrics Act originally empowered the Commission to make "such rules and regulations as may be necessary and proper for purposes of administration and enforcement of [the Act]," 67 Stat. 113 (1953), language similar to that contained in section $6(\mathrm{~g})$ of the FTCA. See text accompanying note 16 supra. Congress amended the provision in 1967, specifically limiting its scope to the "maintenance of records relating to fabrics, related materials, and products" and added that any violation of such rules would be a violation of section 5(a) of the FTCA. 15 U.S.C. § 1194 (c) (1970). The Report of the House Committee on Interstate and Foreign Commerce stated that the purpose of the amendment was to "[permit] flammability standards and other regulations to be issued under rulemaking procedures rather than having them fixed by law as is now the case." H.R. REP. No. 972, 90th Cong., 1st Sess. 1 (1967).

38. Burrus \& Teter 1125. See also H.R. REP. No. 3236, 81st Cong., 2d Sess. 3334 (1951) (where the Select Committee on Small Busimess recommended that "further study should be given to the possibility of granting to the Commission a comprehensive rulemaking power"). On the other hand, the isolated views of one Congress as to the construction of a statute adopted by another Congress are not determinative of legislative intent. Cf. Umited States v. Southwestern Cable Co., 392 U.S. 157, 170 (1968). Also, it is possible that the unequivocal grants of rulemaking power in the fur and textile products areas were made in response to the FTC's reluctance to employ substantive rulemaking under the FTCA and to insure that this type of rulemaking was undertaken in these specific areas.

39. See notes 21-33 supra and accompanying text.

40. See notes 34-38 supra and accompanying text.

41. See notes 13-20 supra.

42. See National Petroleum Refiners Ass'n v. FTC, 482 F.2d 672, $693-94$ n.27

(D.C. Cir. 1973). See note 9 supra.

43. 338 U.S. 632 (1950).

44. Id. at 640 . 
(that of requiring corporations to file special reports pursuant to section $6(b))^{45}$ to aid enforcement of a final cease and desist order. ${ }^{46}$ The Court rejected the argument that sections 5 and 6 were directed toward different functions, enforcement and investigations respectively, and concluded that the FTCA "must . . . be read as an integrated whole." 47 Similarly, in FTC v. Dean Foods $\mathrm{Co}^{48}$ the Court sustained the FTC's power to petition the courts of appeals for preliminary relief to postpone corporate mergers pending the outcome of cease and desist order proceedings, despite the absence of express statutory authorization to do so. The Court concluded in so liolding that "[s]uch ancillary powers have always been treated as essential to the effective discharge of the Commission's responsibilities." 49

Moreover, decisions in which the Supreme Court has construed rulemaking provisions in the enabling statutes of other regulatory agencies suggest that such provisions should be liberally interpreted. For example, in National Broadcasting Co. v. United States, ${ }^{50}$ the Court sustained the issuance of regulations of the Federal Communications Commission (FCC) aimed at eliminating limitations on programming created by chain broadcasting agreements, despite the absence of express statutory authorization for the FCC to deal with the contractual relations between networks and their affiliates. ${ }^{51}$ In reasoning similar to that followed in the Dean Foods case, the Court determined that such authority was implicit in the comprehensive nature of the FCC's statutory mandate to oversee the entire broadcast industry and to exercise its broadcast licensing power in the "public interest, convenience, or necessity." ${ }^{2}$ Furthermore, the Court rejected the argu-

45. 15 U.S.C. $\S 46(\mathrm{~b})(1970)$.

46. 338 U.S. at 647-51.

47. Id. at 650. The reasoning employed in Morton Salt has been followed in subsequent cases to sustain FTC rules, issued pursuant to section $6(\mathrm{~g})$ of the FTCA, which specified the details of service of process under sectiou $5(f)$ of the FTCA, 15 U.S.C. $\$ 45(f)$ (1970). Hunt Foods and Indus. Inc. v. FTC, 286 F.2d 803 (9th Cir. 1960); United States v. San Juan Lumber Co., 313 F. Supp. 703 (D. Colo. 1969).

48. 384 U.S. 597 (1966).

49. Id. at 607 . The Court elaborated: "It would stultify the congressional purpose [in entrusting the Commission with enforcement of the Clayton Act and granting it the power to order divestiture in appropriate cases] to say that the Commission did not have the incidental power to ask the courts of appeals to exercise their authority derived from the All Writs Act." Id. at 606 (emphasis added).

50. 319 U.S. 190 (1943).

51. Id. at 217-20. The Court's willingness to permit the FCC to regulate matters beyond the express scope of its powers was also based upon the absence of anything in the legislative history requiring a "cramping construction" of the statute. Id. at 21721.

52. Id. at $215-17$. 
ment that the general rulemaking provisions in the FCC's enabling statute, which are placed among provisions dealing primarily with technical and financial aspects of broadcasting operations, ${ }^{63}$ could not be employed to particularize the substantive standards embodied in the agency's statutory mandate, which is set forth in a separate section of the statute. ${ }^{54}$

In a 1973 decision, Mourning v. Family Publications Service, Inc., ${ }^{65}$ the Supreme Court rejected the argument that provisions of the Truth in Lending Act, ${ }^{56}$ which specify that disclosure of contract financing information by merchants is required where finance charges actually are, or may b.e, imposed, ${ }^{57}$ preclude the Federal Reserve Board from adopting a broader rule which requires similar disclosure in any transaction imvolving payment in four or more installments. ${ }^{58}$ In so holding the Court found that the rule, while not specifically authorized, was not only consistent with, but also furthered the policies of consumer protection underlying the Act:

Where the empowering provision of a statute states simply that the agency may "make ... such rules and regulations as may be necessary to carry out the provisions of this Act," we have held that the validity of a regulation promulgated thereunder will be sustained as long as it is "reasonably related to the purposes of the enabling legislation." 59

In addition to the above cases, which indicate that agency rule-

53. 47 U.S.C. $\$ \S 303(i)$, (r) (1970). Section 303 permits the FCC to exercise a variety of powers "as public convenience, interest, or necessity requires." Subsection (i) applies to chain broadcasting and subsection ( $r$ ) permits rulemaking necessary to carry out the provisions of the FCA. The remaining provisions of section 303 apply to electronic apparatus and technical requirements of issuing licenses.

54. 319 U.S. at 215-17. See note 51 supra and accompanying text.

55. 411 U.S. 356 (1973).

56. 15 U.S.C. $\$ \S 1601$ et seq. (1970).

57. Id. $\$ 1631$.

58. The "four installment rule" was, however, adopted under authority of a general rulemaking provision, id. $\S 1604$, specifically applicable to the Board's enforcement functions. 411 U.S. at 361-62.

59. 411 U.S. at 369 (citations omitted). The "four installment rule" was found to be a reasonable ineans of attacking the problem of hidden finance charges. $I d$. at 371 . Chief Justice Burger, writing for the majority, observed that "[t]o accept respondent's argument [that the FRB's enforcement authority was confined to the literal terms of the statute] would undermine the flexibility songht in vesting broad rulemaking authority in an administrative agency." Id. at 372, citing American Trucking Ass'n Inc. v. United States, 344 U.S. 298, 309-10 (1953). In American Trucking, the Court upheld Interstate Coinmerce Commission regulations, adopted pursuant to a broad ruleinaking provision, which limited the use of leased eqnipment by carriers authorized under the Motor Carrier Act, 49 U.S.C. $\$ \S 301$ et seq. (1970), although the subject of equipment leasing was not specifically mentioned in the statute. 
making powers are to be construed broadly, other decisions reveal a judicial willingness to sustain agency rulemaking even where the apparent right of regulated parties to have their interests determined in an agency adjudication is thereby abridged. In the leading case of United States v. Storer Broadcasting Co., ${ }^{\circ 0}$ the Supreme Court confronted the question of whether the FCC could issue regulations which provided that an additional broadcasting license would not be granted to applicants who already owned a specified number of licensed stations, even though the FCC's enabling statute specified that adverse determination of license applications be made only after a "full hearing." 1 The Court validated the rules by concluding: "We do not read the hearing requirement . . . as withdrawing from the power of the Commission, the rulemaking authority necessary for the orderly conduct of its business ...." ${ }^{22}$ The Storer rationale has not been confined to rulemaking by the FCC; ${ }^{63}$ and it has been applied to sustain substantive rulemaking even where such rulemaking restricts the rights of regulated parties to have the status of an existing privilege determined in an adjudicatory context. ${ }^{84}$

60. 351 U.S. 192 (1956).

61. Act of July 16, 1952, ch. 879, § 7, 66 Stat. 715.

62. 351 U.S. at 202. The FCC asserted as the basis for its authority the rulemaking provisions of section 303, 47 U.S.C. $\$ 303(f)$, (r) (1970), and another provision, id. $\$ 154(\mathrm{i})$, which permits ruleunaking "necessary in the execution of its functions." 351 U.S. at 201.

The Court emphasized that the "Communications Act must be read as a whole and with appreciation of the responsibilities of the body charged with its fair and efficient operation." Id. at 203 (emphasis added).

63. Storer was followed in FPC v. Texaco, Inc., 377 U.S. 33 (1964). At issue in that case was the validity of regulations issued by the Federal Power Commission, pursuant to section 16 of the Natural Gas Act, 15 U.S.C. \& 717(o) (1970), which provided for summary rejection of applications for certificates of public convenience and necessity to supply pipelines with natural gas if the supply contracts, submitted in support of the applications, contained price clauses not "permitted" by the regulations. 377 U.S. at 34-37. Section 7 of the Act specified that applications for certificates could be denied only after an agency hearing. 15 U.S.C. $\$ 717(f)$ (1970). The Court concluded that "the statutory requirement for a hearing ... does not preclude the Commission from particularizing statutory standards through the ruleinaking process and barring at the thresiold those who neither measure up to them nor show reasons why in the public interest the rule should be waived." 377 U.S. at 39.

64. In American Airlines, Inc. v. CAB, 359 F.2d 624 (D.C. Cir.), cert. denied, 385 U.S. 843 (1966), the plaintiffs challenged the validity of a rule which was issued by the Civil Aeronautics Board, pursuant to a grant of authority to promulgate substantive rules, 49 U.S.C. $\$ 1354$ (a) (1970), and which conferred an exclusive privilege to all-cargo air carriers to provide "blocked space" (discount rate) service. 359 F.2d at 625-27. The rule was upleld notwithstanding that it operated to modify the outstanding certificates of combination carriers (passengers and cargo), which had previously been allowed to offer such service, and that the statute, 49 U.S.C. $\$ 1371(\mathrm{~g})$ (1970), required that certificates be altered only after notice and a hearing. 359 F.2d 
Recently, in Weinberger v. Hynson, Westcott \& Dunning, Inc., ${ }^{\text {or }}$ the Supreme Court reaffirmed the Storer analysis in sustaining regulations issued by the Food and Drug Administration (FDA) which provide that unless the manufacturer of a drug under FDA scrutiny submits data in accordance with specified scientific testing criteria to support the claimed efficacy of the drug, the FDA will withdraw market clearance for the drug without a hearing. ${ }^{\circ 0}$ Notwithstanding the statutory requirement that the FDA conduct a hearing prior to withdrawing its approval of a drug, ${ }^{67}$ the Court held that such a requirement does not prevent the agency from "particularizing statutory standards through the rulemaking process" and from denying a hearing to those who fail to meet such standards. ${ }^{68}$ The Court observed that the FDA "could not fulfill its statutory mandate" if the status of each of the

at 626. The court of appeals found Storer dispositive:

[T] he Storer doctrine is not to be revised or reshaped by reference to fortuitous circumstances. It rests on a fundamental awareness that rule making is a vital part of the administrative process, particularly adapted to and needful for sound evolution of policy in guiding the future development of industries subject to intensive administrative regulation in the public interest, and that such rulemaking is not to be shackled, in the absence of clear and specific Congressional requirement, by importation of formalities developed for the adjudicatory process and basically unsuited for policy rule making. Id. at 629 (emphasis added).

See also WBEN v. United States, 396 F.2d 601 (2d Cir.), cert. denied, 393 U.S. 914 (1968) (FCC rules altering the operations of pre-sunrise radio broadcasters upheld, even though a modification of a broadcaster's license ordinarily required a hearing); California Citizens Band Ass'n v. United States, 375 F.2d 43 (9th Cir. 1967) (FCC rules operating to modify the powers of all members of a certain class of citizens radio service hicensees held valid despite the fact that an individualized hearing was required for license modification); Air Line Pilots Ass'n Int'1 v. Quesada, 276 F.2d 892 (2d Cir. 1960) (FAA regulation prohibiting further service by airline pilots after their sixtieth birthday upheld against the claim that it had the effect of modifying existing pilots' licenses without individualized hearings). See generally Rulemaking to Deny Adjudications 1086.

65. 412 U.S. 609 (1973).

66. Id. at $620 ; 21$ C.F.R. $\S \S 130.12(a)(5), 130.14(b)$ (1973). The regulations were issued pursuant to a provision of the Federal Food, Drug, and Cosmetic Act of 1938, 21 U.S.C. $\$ \S 301$ et seq. (1970), which einpowers the FDA to make regulations in aid of enforcement of the statute, id. $\$ 371$ (a).

All "drugs" come within the requirements of the Drug Amendments of 1962, Act of Oct. 10, 1962, Pub. L. No. 87-781, 76 Stat. 780 (codified in sections of 21 U.S.C.), which amended portions of the 1938 Act, and redefined "new drug" to imclude not only those drugs which have not been recognized among experts as safe but also those not recognized as effective for their intended use. 21 U.S.C. $\$ 321(\mathrm{p})(1)$ (1970). Products classified as "new drugs" caunot be markcted without FDA approval in the form of an approved new drug application (NDA). Id. $\$ 355(\mathrm{a})$. The FDA is directed to refuse NDAs or, in certain instances, to withdraw existing NDAs unless there is a showing of "substantial evidence" that the drug in question is both safe and effective. Id. $\$ \S 355$ (d), (e), as amended, 21 U.S.C. $\$ 355$ (e) (Supp. II 1972).

67. 21 U.S.C. $\$ 355(\mathrm{e})$, as amended, 21 U.S.C. $\$ 355$ (e) (Supp. II 1972).

68. 412 U.S. at 620-21, quoting FPC v. Texaco, Inc., 377 U.S. 33, 39 (1964). 
several thousand substances submitted annually for approval had to be determined in a full agency hearing. ${ }^{.9}$

These decisions upholding substantive rulemaking efforts by other agencies, while not determinative of the proper scope of section $6(\mathrm{~g}),{ }^{70}$ reveal a clearly articulated judicial concern for the capacity of regulatory agencies to effectively pursue their statutory mandates and a recognition that substantive rulernaking may properly be em-

69. 412 U.S. at 621 . The Court emphasized the futility of holding individualized hearings where the application itself reveals that the applicant cannot succeed in meeting the evidentiary burden. Id. at 620-21.

The Court also approved the FDA's practice of comprehensively defining all products within a generic category as "new drugs" for which agency approval is required, see note 66 supra, by means of a declaratory order issued pursuant to a single administrative proceeding. See section 5(d) of the APA, 5 U.S.C. $\$ 554(\mathrm{e})$ (1970). In so doing, the Court rejected the argument that the manufacturer of each product was entitled to individualized hearings. 412 U.S. at 624-26.

The Court noted that for every approved drug there were at least five similar products which had been marketed without approval, but under the implicit security of the FDA's approval of the "pioneer" drug. Determining the status of these "me-too" drugs on a case-by-case basis, the Court stated, would "paralyze" the FDA. Id.

In a coinpanion case, Weinberger v. Bentex Pharmaceuticals, Inc., 412 U.S. 645 (1973), the FDA's claim to have jurisdiction to decide in an agency hearing whether a product is a "new drug," rather than having to litigate that issue in a district court, was sustained. The Court concluded:

The deluge of litigation that would follow if "me-too" drugs and [over-thecounter] drugs had to receive de novo hearings in the courts would ... not [inure] to the interests of the public that Congress was anxious to protect .... In a case much more clouded with doubts than this one, we held that we would not "in the absence of compelling evidence that such was Congress' intention .... prohibit administrative action imperative for the achievement of an agency's ultimate purposes. Permian Basin Area Rate Cases, 390 U.S. 747-780 [1968]." 412 U.S. at 653 (emphasis added).

70. Administrative agencies are not "fungibles," see American Airlines, Inc. v. CAB, 359 F.2d 624, 635 (D.C. Cir.), cert. denied, 385 U.S. 843 (1966) (Burger, J., dissenting); the purposes underlying their creation, the respective legislative histories accompanying the enabling statutes, and the overall scheme of those statutes vary from one agency to another.

Unlike the commerce-wide jurisdiction of the FTC, see 15 U.S.C. $\$ \S 45(a)(1),(6)$ (1970), other regulatory agencies were created to provide comprehensive regulation of particular segments of the economy such as natural gas and electric power (FPC), 15 U.S.C. $\S \$ 717$ et seq. (1970); foods, drugs, and cosmetics (FDA), 21 U.S.C. $\S \S 301$ et seq. (1970); communications (FCC), 47 U.S.C. $\$ \$ 151$ et seq. (1970); transportation (ICC), 49 U.S.C. $\S \S 301$ et seq. (1970); and airlines (CAB), id. \$§ 1301 et seq. Further, both the language and the context of the general rulemaking provisions in the enabling statutes of other federal regulatory agencies more clearly support substantive rulemaking than does section $6(\mathrm{~g})$ of the FTCA. Compare 15 U.S.C. $\$ 46(\mathrm{~g})(1970)$ (FTC with id. § 717(o) (FPC); 47 U.S.C. \$§ 154(i), 303(f), (r) (1970) (FCC); 49 U.S.C. $\S \S 304(\mathrm{a})$, (b) (1970) (ICC); and id. $\$ \S 1324(\mathrm{a}), 1354$ (a) (CAB). Significantly, in each of the enabling statutes of these agencies, unlike the FTCA, there are provisions establishing penalties for violation of agency regulations. See 15 U.S.C. \$ 717t(b) (1970) (FPC); 47 U.S.C. $\$ 312(\mathrm{a})(4)$ (1970) (FCC); id. $\$ \S 1471(\mathrm{a})$, 1472(a) (CAB). See also Note, supra note 20, at 346. 
ployed to enhance that capacity. ${ }^{71}$ Moreover, they indicate that substantive rulemaking can be utilized in conjunction with agency hearings to define and enforce broad substantive provisions in an enabling statute. ${ }^{72}$

In addition to the above cases which implicitly recognize the valuable role that rulemaking can play in an agency's carrying out its enforcement responsibilities, other recent cases indicate that use of rulemaking in formulating agency policy is often fairer to regulated parties than adherence to a case-by-case approach. In $N L R B v$. Wyman-Gordon Co. ${ }^{73}$ the National Labor Relations Board, which is specifically authorized by statute to promulgate substantive rules, ${ }^{74}$ sought to apply in an adjudicatory proceeding against Wyman-Gordon, a "rule" developed in a previous adjudication. ${ }^{75}$ The Supreme Court upheld the NLRB's order agamst Wyman-Gordon even though six Justices, including Harlan and Douglas, who dissented from the actual holding, viewed the Board's efforts as a near-deliberate atteinpt to make prospective rules of general applicability without meeting the requirements for rulemaking set forth in Section 4 of the APA. ${ }^{78}$ The

71. See, e.g., Mourning v. Family Publications Serv., Inc., 411 U.S. 356, 37173, 376 (1973); of. American Airlines, Inc. v. CAB, 359 F.2d 624, 633 (D.C. Cir.), cert. denied, 385 U.S. 843 (1966). See notes 55-69 supra and accompanying text.

72. See, e.g., Wemberger v. Hynson, Westcott \& Dunning, Inc., 412 U.S. 609, 62022 (1973); FPC v. Texaco, Inc., 377 U.S. 33, 44 (1964); United States v. Storer Broadcasting Co., 351 U.S. 192, 203, 205 (1956); American Airlines v. CAB, 359 F.2d 624, 629-33 (D.C. Cir.), cert. denied, 385 U.S. 843 (1966); Air Line Pilots Ass'n, Int'l v. Quesada, 276 F.2d 892, 896 (2d Cir. 1960); 1 K. Davs $\$ \$ 7.02,7.06$; Rulemaking to Deny Adjudication 1093-96, 1112-14; see notes 60-69 supra and accompanying text. But see Robinson 519-25.

73. 394 U.S. 759 (1969).

74. 29 U.S.C. $\$ 156(1970)$.

75. In the prior adjudication, Excelsior Underwear, Inc., 156 N.L.R.B. 1236 (1966), the Labor Board considered objections of unions which lad lost at least two representation elections, purportedly because the compamies involved had not furnished the unions with lists of the names and addresses of employees eligible to vote. The NLRB "invited certain interested parties" to file amici briefs and to participate in the proceedings. Id. at 1238 . The decision reached by the NLRB in Excelsior announced the requirement, "[applicable] in all election cases," that compamies must provide unions with such lists. Id. at 1239-40. The requirenent was not applied, however, to the firms in Excelsior, but was to be applied prospectively. Id. at $1240 \mathrm{nt} .5$.

The Wyman-Gordon litigation arose upon complaint of several unions which had lost representation elections among the employees of that firm. As a remedial measure, the NLRB ordered new elections. 394 U.S. at 761. In response to the company's refusal to provide the unions with the names and addresses of its employees, the NLRB, apparently in conformance with the Excelsior rule, ordered that such lists be made available. Id. at 761-63.

76. Four justices, a plurality, objected to the directive formulated in Excelsior, see note 75 supra, finding it equivalent to a "rule" as defined in section 2(c) of the APA, 5 U.S.C. $\& 551(4)(1970)$, and therefore void because it was not issued pursuant to 
common point of agreement centered on the absence of fairness in this type of policymaking, as was expressed by Justice Fortas in the plurality opinion:

The rulemaking provisions of [the APA], which the Board would avoid, were designed to assure fairness and mature consideration of rules of general apphication. They may not be avoided by the process of making rules in the course of adjudicatory proceedings. ${ }^{77}$

The standard of fairness suggested in Wyman-Gordon has been followed recently in Bell Aerospace Co., Division of Textron, Inc. v. $N L R B,{ }^{78}$ in which the Second Circuit refused to enforce an NLRB order which was based upon a radical change in agency policy, and upon which regulated parties had long placed their reliance, ${ }^{79}$ because it was adopted in a prior adjudication rather than pursuant to rulemaking proceedings. ${ }^{80}$ Taken together, Wyman-Gordon and Bell Aerospace sug-

the rulemaking procedures set forth in section 4 of the APA, id. $\$ 553$; however, they were of the opinion that sucl a directive could be, and was, validly redeveloped in the Wyman-Gordon case. 394 U.S. at 753-66. Three justices, led by Justice Black, lad no objection to the development of a prospective directive in an adjudication or its application to Wyman-Gordon. Id. at 769-75. Justices Harlan and Douglas each wrote separate dissenting opinions, and both agreed that the directive was a "rule" and, not having been adopted pursuant to APA requirements for rulemaking, was totally void. $I d$. at $775-83$.

77. 394 U.S. at 764 (citations omitted). Justice Douglas, in dissent, observed:

The [APA] rule-making procedure performs important functions. It gives notice to an entire segment of society of those controls or regimentation that is forthcoming. It gives an opportunity for persons affected to be heard $\ldots$. Id. at 777 .

This view was initially suggested in SEC v. Clienery Corp., 332 U.S. 194 (1947), where the Supreme Court upheld an SEC "rule," adopted during reorganization proceedings, which prohibited trading in company securities by management personnel pending the outcome of the reorganization. The Court felt that the agency should be permitted to exercise discretion in clioosing which procedure-rulemaking or adjudication-is more appropriate for the evolution of statutory standards. Id. at 201-03. However, Justice Murphy, writing for the majority emphasized that

[t] $]$ he function of filling in the interstices of the Act should be performed, as much as possible through [the] quasi-legislative promulgation of rules to be applied in the future. Id. at 202 .

78. 475 F.2d 485 (2d Cir. 1973), rev'd, 42 U.S.L.W. 4564 (U.S. Apr. 23, 1974).

79. The Board reversed "a long-standing and oft-repeated policy" regarding the types of employees protected under the National Labor Relations Act. 475 F.2d at 497.

80. Id. at 496-97. Judge Frieudly, writing for the court, relied heavily upon the suggestion by the Supreine Court in Wyman-Gordon, see notes 73-77 supra and accompanying text, for his couclusion that the Board was required to proceed by rulemaking procedures in formulating policy. He concluded that "when the [NLRB] has so loug been committed to a position, it should be particularly sure that it has all available information before adopting another, in a setting where nothing stands in the way . . . of rulemaking. . . ." Id. at 497.

The Supreme Court recently reversed the Second Circuit in Bell Aerospace. The Court held that Chenery and Wyman-Gordon made "plain that the Board is not pre- 
gest an emerging willingness on the part of courts to require an agency, where its substantive rulemaking authority is clear, to develop policy innovations through rulemaking procedures, at least in those instances where to do otherwise would be unnecessary and unfair to regulated parties not before the agency. ${ }^{81}$ Furthermore, they indicate a recognition by the courts of the adequacy of rulemaking procedures to protect the rights of regulated parties in the process of agency policymaking. ${ }^{82}$

\section{JUdICIAL RESOLUTION}

\section{The District Court's Decision}

Despite the apparent cogency of the above decisions in which rulemaking provisions in the enabling statutes of other agencies have been broadly interpreted, the district court in National Petroleum Refiners $v . F T C$ found them to be inapposite to the question of the proper construction of section $6(\mathrm{~g})$ of the FTCA. ${ }^{83}$ Instead, the court focused upon the location of that rulemaking provision within the statute $^{84}$ and the legislative history of the FTCA ${ }^{85}$ and concluded that because "[s]ection $6(\mathrm{~g}) \ldots$ was intended only as an authorization for internal rules of organization, practice, and procedure, . . . the Commission has no substantive, legislative rulemaking authority under the FTCA." 36

The court acknowledged that the language of section $6(\mathrm{~g})$ might appear "at first impression" to support substantive rulemaking.87 However, since it viewed the operative effect of Trade Regulation Rules as "circumventing the extensive due process procedures expressly provided for in section 5 of the FTCA," the district court re-

cluded from announcing new principles in an adjudicative proceeding and that the choice between rulemaking and adjudication lies in the first instance with the Board's discretion." NLRB v. Bell Aerospace Co., 42 U.S.L.W. 4564, 4572 (U.S. Apr. 23, 1974). However, the Court observed that "there may be situations where the Board's reliance on adjudication would amount to an abuse of discretion . . . ." Id.

81. See notes 73-80 supra and accompanying text.

82. See NLRB v. Wyman-Gordon Co., 394 U.S. 759, 764, 777-79; Bell Aerospace Co., Div. of Textron, Inc. v. NLRB, 475 F.2d 485, $495-97$ (2d Cir. 1973), rev'd, 42 U.S.L.W. 4564 (U.S. Apr. 23, 1974).

83. National Petroleum Refiners Ass'n v. FTC, 340 F. Supp. 1343,1349 n.32 (D.D.C. 1972). See notes 43-69 supra and accompanying text. The court took the position that "the FTC is materially distinct from other administrative bodies" because it is primarily an investigative, rather than a regulatory body. $340 \mathrm{~F}$. Supp. at 1345.

84. See notes 13-20 supra and accompanying text.

85. See notes 21-33 supra and accompanying text.

86. $340 \mathrm{~F}$. Supp. at 1345-48.

87. Id. at 1345 . 
quired the Commission to provide additional, persuasive evidence that the asserted authority was conferred upon it by Congress in $1914{ }^{88}$ Because there was no express indication in section $6(\mathrm{~g})$ or in the final floor debates that rulemaking was to be used as an alternative means of defining and enforcing the FTCA's substantive requirements, the court concluded that the scope of section $6(\mathrm{~g})$ was limited, as was the rulemaking provision in the House bill, to non-substantive matters. ${ }^{89}$ Furthermore, the court found the rejection by the House of several amendments, which would have enabled the FTC to make substantive rules, to be a significant indication of Congress' intent to withhold such rulemaking authority. ${ }^{90}$ The court observed that subsequent to its creation, the FTC was conventionally viewed as lacking the authority to make substantive rules ${ }^{91}$ and found the specific authorizations of the FTC to exercise such power only in severely constricted areas to be another "critical factor" which militated against the Commission's claim that it was granted an unrestricted rulemaking power in $1914 .{ }^{92}$ Having concluded that the only rulemaking provision in the FTCA did not authorize substantive rulemaking, the court found it impossible, because of the contrary nature of the legislative history, to accept the FTC's alternative contention that rulemaking authority could be implied from its broad mandate to prevent unfair competition. ${ }^{93}$ Finally, the court characterized the Commission's argument that policymaking through legislative rulemaking would not only en-

88. Id. at $1346-47$.

89. Id. at 1345-48. District Judge Robinson emphasized that

[i]f Congress at any time had intended to confer upon the Commission the authority to prescribe substantive law in such a manner as to vitiate the substantial procedural safeguards specified in the Act itself, there certainly would be some reference to this extraordmary grant of power in the Act or the legislative history. Id. at 1347.

See notes 29,30 and accoinpanying text.

90. 340 F. Supp. at 1346 . See note 25 supra and accompanying text.

91. See note 35 supra and accompanying text.

92. 340 F. Supp. at $1347,1349-50$. See notes 37,38 supra and accompanying text. The district judge reasoned that such specific grants of rulemaking power would be "meaningless and superfluous" if Congress had granted such authority to the Counmission in 1914. Id. at 1347.

93. Id. at 1349. The FTC argued that since the FTCA's legislative history indicated that the Commission was to have broad powers to define the statutory standard of illegality, see note 33 supra and accompanying text, the power to make legislative rules concerning substantive matters could be implied, on the basis of necessity, from the statutory mandate itself. See also 1964 Statement of Basis 8369, 8370. The court conceded that grants of substantive rulemaking power have been implied from imprecise statutory provisions, but never where the legislative history was so "overwhelmingly contrary," 340 F. Supp. at 1349, and distinguished National Broadcasting Co. v. United States, 319 U.S. 190 (1943) on this basis, 340 F. Supp. at 1349 n.32. See notes 50-54 supra and accompanying text. But see K. DAVIS, DISCRETIONARY JUSTICE $65-77$ (1969). 
hance the agency's effectiveness, but also would be fairer to regulated parties, as a "bootstrap operation" intended to persuade the court to "supply" authority which Congress had not itself conferred. ${ }^{94}$

\section{The Court of Appeals' Decision}

In contrast, the court of appeals in National Petroleum Refiners found the language of section $6(\mathrm{~g})$ sufficiently broad to authorize substantive rulemaking. Conceding that it was "arguable" that the rulemaking power conferred on the Commission by that provision extended only to procedural or housekeeping matters, the court saw "no reason to import such a restriction on the 'rules and regulations' permitted by section $6(\mathrm{~g}) .{ }^{395}$ In reaching this conclusion the court was influenced by several factors. First, it noted the judicial precedents which emphasized "the need to interpret liberally broad grants of rulemaking authority." S6 Such decisions, the court felt, revealed a judicial

94. 340 F. Supp. at 1349-50 nn. 33-36; see Note, supra note 6, at 383 n.113.

95. National Petroleum Refiners Ass'n v. FTC, 482 F.2d 672, 678 (D.C. Cir. 1973), cert. denied, 42 U.S.L.W. 3485 (U.S. Feb. 26, 1974). The court rejected outright the Petroleum Refiners' conteutiou that section $6(\mathrm{~g})$ was limited by its context to matters unrelated to ageucy adjudications by observing that section $6(\mathrm{~g})$ is lacking in words restricting its scope, that section 5 contains no language indicating that adjudication is the exclusive mode of defining the staudard of illegality, and finally, that sectiou $6(\mathrm{~g})$ expressly permits rulemaking to "carry out" all provisions of the FTCA including section 5 adjudications. 482 F.2d at 676 . The court stressed the fact that the use of Trade Regulation Rules "does not in any formal sense circumvent" the mode of enforcement set forth in section 5(b) of the FTCA because adjudications must still be held to give legal effect to the policy determination embodied in such rules. Id. at 675,678 . In reaching this conclusion, the court relied upon United States v. Morton Salt Co., 338 U.S. 632 (1950) aud other cases upholding an integral reading of sections 5 and 6 , see notes $43-47$ supra and accompanying text, and upon the broad interpretation given to the Commission's enforcement powers in FTC v. Dean Foods Co., 384 U.S. 597 (1966), see notes 48-49 supra and accompanying text. 482 F.2d at 676-78.

96. 482 F.2d at 678-84. The court relied upon National Broadcasting Co. v. United States, 319 U.S. 190 (1943), and Mourning v. Family Publications Serv., Inc., 411 U.S. 356 (1973), as well as United States v. Storer Broadcasting Co., 351 U.S. 192 (1956), and its progeny. See notes 50-69 supra and accompanying text. Other cases in which imprecise grants of rulemaking power have been lield to support substautive ruleniaking by otber agencies were also cited by the court. 482 F.2d at 680 . Morgan Stanley \& Co. v. SEC, 126 F.2d 325, 332 (2d Cir. 1942) (SEC empowered to issue substantive rules under $\S 20$ of the Public Utility Holding Company Act, 15 U.S.C. $\$ 79 t$ (a) (1970); Borden Co. v. Freemau, 256 F. Supp. 592 (D.N.J. 1966), aff'd per curiam, 369 F.2d 404 (3d Cir. 1966), cert. denied, 386 U.S. 992 (1967) (section 463 of the Poultry Inspection Act, 21 U.S.C. $\$ 463$ (1970), confers power upon Secretary of Agriculture to promulgate rules which classify and establish labeling requirements for poultry products).

The court noted that the FTC, by virtue of its broad substantive provisions of the FTCA, was intended to have a pervasive regulatory impact upon business practices and 
recognition that substantive rulemaking provides an administrative agency with "an invaluable resource-saving flexibility in carrying out its task of regulating parties subject to its statutory mandate."97 The court specifically referred to the Storer line of cases as indicating that substantive rulemaking could be utilized in conjunction with an adjudicatory procedure simce it served to simplify and expedite such proceedings. ${ }^{98}$ Moreover, the court noted that recent decisions such as $W y$ man-Gordon and Bell Aerospace indicate that it may be fairer to regulated parties to utilize rulemaking in the formulation of agency policy rather than to rely totally upon case-by-case adjudication. ${ }^{99}$

Thus, the above decisions convinced the court that the term "rules and regulations" in section 6(g) should be interpreted to authorize substantive rulemaking unless there was found compelling evidence in the Act's legislative history to the contrary. ${ }^{100}$ In contrast to the district court, the court of appeals termed the legislative history "ambiguous," concluding that the Act's framers did not "straiglitforwardly and decisively" confront the precise question of the use of substantive rulemaking to narrow the inquiry in section 5 adjudications. ${ }^{10.1}$ However, the court of appeals found the use of Trade Regu-

is not, therefore, generically dissimilar to other regulatory agencies. See note 33 supra and accompanying text. Consequently, it rejected the appellees' contention, accepted by the district court, see note 83 supra and accompanying text, that the FTC was sui generis-a prosecutorial, rather than a regulatory agency. $482 \mathrm{F.2d}$ at 68485 . In so doing, the court eliminated an initial obstacle to the applicability of the decisions in which the rulemaking powers of other agencies have been broadly interpreted.

97. 482 F.2d at 681 .

98. Id. at $679-80$ n.10.

99. Id. at 681-84. See notes 73-82 supra and accompanying text. The court also cited SEC v. Chenery Corp., 332 U.S. 194 (1947), as authority for that proposition. See note 77 supra. The court conceded that since the agencies involved in those decisions clearly possess substantive rulemaking authority, those opinions were not dispositive of the challenge to the FTC's asserted authority. However, the court found them to be relevant because they

suggest that contemporary considerations of practicality and fairness--specifically the advisability of utilizing the [APA's] rulemaking procedures to provide an agency about to embark on legal innovation with all relevant arguments and information-certainly support the Commission's position here. 482 F.2d at 683 (citations omitted).

The court obviously felt that rulemaking contained inherent advantages over adjudications as a method for the formulation of administrative policy, for in contrasting the two procedures, the court noted that

utilizing rule-making procedures opens up the process of agency policy innovation to a broad range of criticism, advice and data that is ordinarily less likely to be forthcoming im adjudication. Moreover, the availability of notice before promulgation and wide public participation in rule-making avoids the problen of singling out a single defendant among a group of competitors for imitial imposition of a new and inevitably costly legal obligation. Id.

100. See 482 F.2d at 684-86. See note 96 supra and accompanying text.

101. Id. at 686. The court's review of the legislative history of the FTCA 
lation Rules to be "not only consistent with the original framers" broad purposes, but . . . a particularly apt means of carrying them out."102 Unlike the district court, the court of appeals gave little weight to the fact that prior to 1962 the Commission itself had construed its enabling statute as not authorizing substantive rulemaking. ${ }^{103}$ Similarly, although the court conceded that the argument that Congress liad implicitly recognized that the Commission lacked general substantive rulemaking power by passing a series of laws which specifically granted such powers to the Commission in particular areas was a "more troublesome obstacle to the Commission's position," it found it not dispositive. ${ }^{104}$ Moreover, the court noted that the district court's deci-

is set forth in an appendix to the opinion, id. at 698-709. The court concluded that the history of the pertinent 1914 debates leaves us with a few affirmative indications that Section $6(\mathrm{~g})$ encompassed substantive rule-making and a few cryptic indications that this is not so. As a consequence the need to rely on the section's language is obvious. Id. at 709.

102. $1 d$. at 686 . The court noted that congressional debates preceding the enactment of the FTCA reflected a cominon "concern over judicial delay, inefficiency and uncertainty" in the enforcement of the congressional policy against unfair and anticompetitive business practices. Id. at 689 . The court felt that the use of substantive rulemaking would allow the FTC to pursue its regulation of unfair business practice with increased efficiency and expedition. Id. at 690-91. Thus, since the legislative history did not clearly indicate that the framers bad dehiberately withheld substantive rulemaking power from the Commission, $i d$. at 698 , the court concluded that a liberal construction of section $6(\mathrm{~g})$ would be consistent with congressional intent:

In determining the legislative intent, our duty is to favor an interpretation which would render the statutory desigu effective in terms of the policies behind its enactment and to avoid an interpretation which would make such policies more difficult of fulfillment, particularly where as here, that interpretation is consistent with the plain language of the statute. Id. at 689 .

See also FTC v. Fred Meyer, Inc., 390 U.S. 341, 349 (1968); Permian Basin Area Rate Cases, 390 U.S. 747, 776 (1968).

103. The court distinguished the persuasive force of a contemporaneous construction by an agency of its powers under an enabling statute which is based upon special agency expertise from that which is based upon historical and legal analysis, and found the Commission's longstanding reluctance to assert its authority to promulgate substantive rules as falling within the latter, and less persuasive, category. 482 F.2d at 693 95. See Thompson v. Clifford, 408 F.2d 154, 167 (D.C. Cir. 1968). See note 36 supra and accompanying text.

104. Conceding the greater force of this argument . . . we beheve that it must not be accepted blindly. In such circumstances it is equally possible that Congress granted the power out of uncertainty, understandable caution, and a desire to avoid litigation. 482 F.2d at 696 (emphasis added).

See note 37 supra and aceompanying text. The court found "ample evidence" that Congress "lias not wholeheartedly accepted the agency's viewpoint" from statements in committee reports associated with passage of the Fair Packaging and Labeling Act, 15 U.S.C. $\$ \S 1451-61$ (1970), which suggested that the question of the FTC's substantive rulemaking power under the FTCA was unresolved. 482 F.2d at 696-97. See H.R. ReP. No. 2076, 89th Cong., 2d Sess. 22 (1966); S. Rep. No. 1186, 89th Cong., 2d Sess. 40 (1966). Further, the court emphasized that "imputing congressional ratification of a disputed, administrative construction of its powers is . . . 'shaky business.' " 482 
sion would "render the Commission ineffective to do the job assigned it by Congress." ${ }^{105}$ Thus, since a narrow interpretation was not required by the Act's legislative and post-enactment history, the court concluded that the "plain language" of section $6(\mathrm{~g})$, which authorizes the Commission to "make rules and regulations," is sufficient to empower the FTC to promulgate substantive rules of business conduct. ${ }^{108}$

\section{THE IMPACT OF National Petroleum Refiners ON THE FTC}

The court of appeals observed that the FTC "has remained hobbled in its task by the delay inherent in repetitious, lengthy litigation of cases involving complex factual questions under a broad legal standard."107 In theory, by narrowing the scope of inquiry in agency adjudications and by comprehensively determining the illegality of a trade practice employed by many busmess entities, it would appear that the Commission's enforcenent problems could be mitigated by substantive rulemaking. ${ }^{108}$ Recalcitrant firms could still force the FTC to hold individual cease and desist order hearings to enforce a Trade Regulation Rule, but the "streamlined" nature of the proceedings would significantly reduce the FTC's litigation burdens. ${ }^{109}$ Moreover, since the content of a Trade Regulation Rule cannot be challenged in subsequent agency adjudications, it is likely that once the validity of a rule is established (either through judicial review of a rule itself or through judicial review of a cease and desist order based upon a Trade Regulation Rule) those within its scope would comply volun-

F.2d at 697, quoting Power Reactor Dev. Co. v. Int'l Union of Elec. Workers, 367 U.S. 396, 409 (1961).

105. 482 F.2d at 697 .

106. Id. at $678,697-98$. It is significant that the FTC reiterated before the court of appeals the argunient it had made in the district court, that substantive ruleniaking authority could be implied merely fron the FTCA's substantive mandate to prevent unfair practices. Brief for Appellants, FTC, at 10-11. See note 94 supra and accompanying text. The National Petroleum Refiners court did not discuss this argument at all and, on the contrary, stressed the importance of the language of section $6(\mathrm{~g})$. 482 F.2d at $674,685-86,693$. Presuniably, without section $6(\mathrm{~g})$ or its equivalent, the Commission's claim would have been unsuccessful.

107. 482 F.2d at 690 . See note 5 supra and accompanying text.

108. The National Petroleum Refiners court observed that

the Commission will be able to proceed more expeditiously, give greater certainty to businesses subject to the [FTCA], and deploy its internal resources Inore significantly with a mixed systein of rule-making and adjudication than with adjudication alone. With the issues in Section 5 proceedings reduced by existence of a rule delineating what is a violation of the statute or what presumption the Conımission proposes to rely upon proceedings will be speeded up. 482 F.2d at 690.

See notes 4-7 supra and acconpanying text.

109. See notes 6,7 supra and acconpanying text. 
tarily. ${ }^{110}$ Comprehensive treatment will not be appropriate for all types of illegal trade practices, ${ }^{111}$ but where violations of the FTCA occur on an imdustry-wide scale and are static enough to be effectively prohibited by a codified policy determination, substantive rulemaking would tend to enhance the FTC's capacity to prevent such practices. ${ }^{112}$

In a lengthy policy statement issued at the mauguration of the Trade Regulation Rule program, the FTC emphasized that the use of substantive rules, issued pursuant to the procedural requirements

110. There is some empirical data indicating that voluntary compliance would be mcreased as a result of the issuance of Trade Regulation Rules. A computer simulation model of the allocation of Commission resources suggests that regulated parties are not likely to hold out for individual proceedings to enforce a Trade Regulation Rule because the ratio of litigation expenses to chances of securing an ultimate victory would be prohibitive. See Posner, The Behavior of Administrative Agencies, $1 \mathrm{~J}$. LEGAL Studies 305, 313 (1972). See also 1967 FTC ANN. REP. 14-15 (survey showing complete voluntary compliance with two Trade Regulation Rules).

Section 7(d) of the APA, 5 U.S.C. $\$ 556(\mathrm{e})(1970)$, requires that respondents in an agency liearing be permitted to "show the contrary" where the agency seeks to take notice of extra-record facts, including those embodied in a Trade Regulation Rule. The FTC, therefore, must grant respondents an opportunity to demonstrate that special circumstances warrant waiving the applicability of a Rule in a particular case. National Petroleum Refiners Ass'n v. FTC, 482 F.2d 672, 692 (D.C. Cir. 1973); 1964 Statement of Basis 8372 . However, the burden imvolved in sustaining a waiver would likely be a heavy one. See FPC v. Texaco, Inc., 377 U.S. 33, 40 (1964); United States v. Storer Broadcasting Co., 351 U.S. 192, 205 (1956). This would be consistent with the scope of rulemaking authority as interpreted by the National Petrolettm Refiners court imasmuch as legislative rules, which operate with the same force as statutory law, should not be easily bypassed. See Shapiro 966 .

111. For example, it lias been suggested that FTC rulemaking would be particularly inappropriate in the antitrust area where flexible solutions are required to avoid significant perturbations of the economy. See Burrus \& Teter 1127-30; Weston 572-73. In fact, of the more than twenty Trade Regulation Rules issued thus far, see note 7 supra and accompanying text, ouly one lias been aimed at a trade practice in violation of the antitrust laws. Discriminatory Practices in Men's and Boy's Tailored Clothing Industry, 16 C.F.R. $\$ 412$ (1973).

112. See SEC v. Chenery Corp., 332 U.S. 194, 202-03 (1947); Baker, Policy by Rule or Ad-Hoc Approach-Which Should It Be?, 22 LAw \& CoNTEMP. Prob. 658, 661-62 (1957). In addition to the anticipated benefits of expedited proceedings, see notes 6-7 supra and accompanying text, there is soine indication that imcreased use of rulemaking by the FTC will develop the Commission's expertise with regard, at least, to patterns of consumer behavior. First, the Commission will be able to make more extensive use of its accumulated experience derived from previous studies, reports and investigations because section 4 of the APA permits agencies to draw upon, in addition to submitted data, information in its own files in order to determine the final content of a rule. 5 U.S.C. $\$ 553$ (1970); see California Citizens Band Ass'n v. United States, 375 F.2d 43, 54 (9th Cir.), cert. denied, 389 U.S. 844 (1967); Auerbach, supra note 4, at 455-57. Furthernore, in response to the court of appeals' decision in National Petroleum Refiners, the FTC has initiated a major reorganization of its Bureau of Consumer Protection in order to decentralize the rulemaking process-an innovation designed to encourage increased rulemaking activity along narrower lines of agency expertise. BNA ANTITRUST \& TR. REg. Rep. No. 622, A-16, -17 (July 17, 1973). 
set forth in the APA, ${ }^{113}$ would not only provide the agency with the efficiencies of flexibility and comprehensiveness in the development of agency policy, but also would relieve regulated parties of the "disadvantages" of having the substantive requirements of the FTCA developed exclusively in agency adjudications. ${ }^{114}$ Regulated parties may very very well benefit from the fact that substantive requirements adopted in formal rulemaking proceedings apply to all instances of a particular illegal practice simultaneously, whereas proceeding case-by-case against alleged violators places the firms first ordered to cease and desist at a disadvantage vis- $a$-vis their competitors. ${ }^{115}$ Also, the development and codification of agency policy pursuant to public proceedings will make regulation by the FTC both more visible and predictable, thereby facilitating the planning functions of regulated parties. ${ }^{116}$ On the other hand, as several commentators have suggested, the lack of flexibility inherent in adjudication as well as the overall benefits of rulemaking to regulated parties may be overstated. ${ }^{117}$ For example, the wide participation of interested parties, which is asserted to be one of the primary advantages of rulemaking, can be accommodated in adjudication through procedures which provide for expanded notice and participation by intervenors. ${ }^{118}$ Furthermore, by consolidating actions, encouraging the stipulation of facts, and taking official notice of generally known facts, an agency can mitigate the problems of delay and duplicated effort which often reduce the efficiency of the caseby-case approach. ${ }^{119}$ Finally, rules adopted in quasi-legislative pro-

113. 5 U.S.C. $\$ 553$ (1970).

114. 1964 Statement of Basis 8366-68. The arguments put forth by the FTC in favor of rulemaking over adjudication as a method of formulating policy have been thoroughly discussed by a number of commentators. See generally Baker, supra note 112, at 660-65; Fisler, Rule Making Activities in Federal Administrative Agencies, 17 AD. L. REv. 252, 259-60 (1965); Fuchs 788-95; Robinson 513-28; Shapiro 929-42.

115. The FTC is not required to suspend the effectiveness of an order against one firm to cease and desist from illegal conduct until its competitors are similarly prohibited. See FTC v. Universal-Rundle Corp., 387 U.S. 244, 246 (1967); Moog Indus., Inc. v. FTC, 355 U.S. 411, 413-14 (1958). Although the Commission could mitigate this problem of selective enforcement by joining many, or all, nembers of an industry in one proceeding, see Shapiro 935-36, multi-party actions tend to create unmanageable trial situations. Cf. Pepsico, Inc. v. FTC, 472 F.2d 179, 183 (2d Cir. 1972), cert. denied, 414 U.S. 876 (1973).

116. See Shapiro 940-41; FTC Substantive Rulemaking 157.

117. Fuchs 790-95; Robinson 513-28; Shapiro 929-42.

118. See Shapiro 931-32. Moreover, even in rulennaking proceedings the FTC may dispense with the notice and participation requirements where in its discretion it determines sucli requirements to be "impractical, unnecessary, or contrary to the public interest." 5 U.S.C. $\$ 553$ (b)(3)(B) (1970). The Commission has not yet exercised sucli discretion, choosing instead to adhere strictly to the procedural requirements for rulemaking. See FTC Substantive Rulemaking 160.

119. See Shapiro 936-37. 
ceedings can have a retroactive effect similar to those which emerge as a by-product of adjudication -in either case, regulated parties may be required to reverse plans and transactions which were made in rehance upon previous regulatory standards. ${ }^{120}$

More important than the possibility that regulated parties may receive benefits froin FTC substantive rulemaking is the extent to which the rights of regulated parties will be impaired by the Commission's departure from its traditional adjudicatory procedures. Because of the bimding effect in subsequent adjudications of Trade Regulation Rules, the issuance of a rule is itself tantamount to a final determination of the substantive requirements of the FTCA to which affected regulated parties must conform. ${ }^{121}$ Consequently, it is of no small concern to regulated parties that certain trial-type formalities-such as the benefit of statements under oath, and the opportunity to call, examine, and crossexamine witnesses-by which it is possible to exert some control over the admission and probative value of evidence, are not available in rulemaking proceedings. ${ }^{122}$ Storer and its progeny, however, suggest

120. Robinson 517-19; Shapiro 933-35. In the case of the FTC, the cease and desist order may have a prospective effect; thus, there seems to be little difference in the retroactive/prospective effect between cease aud desist orders and Trade Regulation Rules. See Note, supra note 4, at 379-80 (1963).

121. See note 6 supra and accompanying text.

122. See 5 U.S.C. \& 553 (1970). As an integral part of formulating a rule which directs regulated parties to refrain from engaging in a deceptive trade practice, the FTC will often be required to decide upon uniform procedures by which the perfornance characteristics of a particular product are determined. For example, octane ratings do not provide a comprehensive measure of the quality of gasoline, but measure instead its anti-knock characteristics. See Statement of Basis and Purpose of the Trade Regulation Rule for the Posting of Minimum Octane Numbers on Gasoline Dispensing Pumps, 36 Fed. Reg. 23,871 (1971). The current rule appears in 16 C.F.R. $\$ 422.1$ (1973). There are three ways to obtain octane ratings: The "road" method, a timeconsuming and expensive method which requires testing by a fleet of cars under simulated conditions; and the "research" aud "inotor" inethods, which are laboratory procedures which test gasoline by utilizing a one-cylinder engine under varying conditions. See 1972 Developments 336 n.4. Defendants' Memorandum in Support of Motion to Dismiss or, in the Alternative, for Summary Judgment at $47-48$, National Petroleum Refiners Ass'n v. FTC, 340 F. Supp. 1343 (D.D.C. 1972). The FTC decided upon the average minimum laboratory octane number or ( $R$ (research inethod) $+M$ (motor method)) $/ 2$ as the uniform testing standard, the results of which must be posted on dispensing pumps. 36 Fed. Reg. at 23,882-83 (1971). The Commission's determinations concerning testing procedures and the effect of octane ratings upon consumer behavior were based upon its "accumulated knowledge and experience and the Record in [the rulemaking] proceeding[s] . . ." Statemeut of Basis, supra, at 23,880; see note 8 supra and accompanying text. It is significant that the factual bases of the Commission's final determination were derived from statements given without the benefit of oath and not subject to cross-exammation. This procedure precluded the Petroleum Refiners froin presenting a comprehensive rebuttal of the factual support for the rule and the inferences drawn therefrom. Plaintiffs' Answer to Defendants' Mem- 
that such formalities are not essential to protect regulated parties where the issues to be resolved are generally applicable to a class of parties or subjects and primarily require policy judgments by the agency which are appropriately within its jurisdiction and expertise. ${ }^{128}$ The FTC, in fact, has recognized the need to confine substantive rulemaking to problems for which consolidated treatment is appropriate $^{124}$ and has shown, in its comparatively brief history of substantive rulemaking, a conscientious effort to accurately synthesize and consider the data and views submitted by interested parties in rulemaking proceedings. ${ }^{125}$ Nonetheless, since data introduced in rulemaking proceedings are not subjected to the scrutiny afforded by crossexamination, erroneous inferences and judgments may be incorporated into a rule to the detriment of regulated parties. ${ }^{126}$

Unless an agency's enabling statute requires the contrary, rulemaking proceedings do not produce a formal record as do administrative hearings. ${ }^{127}$ Thus, whether a Trade Regulation Rule is reviewed by a court prior to enforcement, ${ }^{128}$ or as the underlying basis of a cease and desist order, the FTC would not be required to demonstrate that such a rule is supported by "substantial evidence," the probative burden required to be met to support a determination made in adjudication, that a particular practice is unfair or deceptive under the FTCA. $^{129}$ Presumably, a Trade Regulation Rule will be upleld un-

orandum in Support of Motion to Dismiss or, in the Alternative, for Summary Judgment at 49-55, National Petroleum Refiners Ass'n v. FTC, 340 F. Supp. 1343 (D.D.C. 1972); Brief for Appellees, National Petroleum Refmers Ass'n at 2, Natioual Petroleum Refiners Ass'n v. FTC, 482 F.2d 672 (D.C. Cir. 1973). But see Robinson 530-31, 538.

123. See note 72 supra and accompanying text.

124. 1964 Statement of Basis 8368,8372 .

125. FTC Substantive Rulemaking 147-49. See National Petroleum Refiners Ass'n v. FTC, 482 F.2d 672, 683 (D.C. Cir. 1973).

126. See note 122 supra and accompanying text.

127. See 5 U.S.C. $\$ \$ 553,556,557,706(2)$ (E) (1970).

128. Pre-enforcement review of agency mles has been cited as one of the primary benefits to regulated parties because the merits of a regulated party's status are not yet at issue before the agency. See, e.g., 1964 Statement of Basis 8368; Baker, supra note 112, at 664-65; Rulemaking to Deny Adjudication 1106-10. However, there is some question as to whether such review may be obtained where an agency's enabling statute, like the FTCA, provides only for review of orders. See PBW Stock Exch., Inc. v. SEC, 485 F.2d 718 (3d Cir. 1973), petition for cert. filed, 42 U.S.L.W. 3434 (U.S. Jan. 21, 1974) (No. 73-1134). See Note, Reviewability of Administrative Action: The Elusive Search for a Pragmatic Standard, 1974 DUKE L.J. 382, 393-96, in 1973 Developments, for a discussion of this case.

129. Under the APA the "substantial evidence test" applies only to agency action "reviewed on the record of an agency hearing provided by statute," 5 U.S.C. \$ 706 (2)(E) (1970). This test applies to rulemaking only "when rules are required by statute to be made on the record after opportunity for an agency hearing." 5 U.S.C. 
less it is found to be "arbitrary or capricious."130 In the case of the FTC, however, the disparity in the standards for review of rules and orders nay be relatively insignificant inasmuch as the Commission's determinations, based upon agency hearing records have in the past been given much deference by reviewing courts. ${ }^{131}$ Thus, while substantive rulemaking under section 4 of the APA may not provide protection equivalent to trial-type formalities, it is entirely possible, on the basis of the Commission's past history of responsiveness and restraint, that regulated parties, as a whole, will be adequately protected from abuses. On the other hand, the use of Trade Regulation Rules promises to be a means whereby the Commission can assert its expertise, especially in the burgeoning area of consumer protection, and more effectively enforce the FTCA. In short, the potential for such rulemaking to enhance the FTC's capacity to pursue its statutory mandate probably outweighs the possibility that regulated parties will be more vulnerable to improper regulatory action. ${ }^{132}$

\section{CONCLUSION}

The decision in National Petroleum Refiners contravened the prevailing view among commentators ${ }^{133}$ and former statements by the Commission itself ${ }^{134}$ that the FTC, unlike most administrative agencies, lacked statutory authority to promulgate substantive rules. In holding to the contrary, the court of appeals specifically denied that it did so on the basis of "a policy judgment as to what mode of procedure-adjudication alone or a mixed system of rulemaking and ad-

$\S 553$ (c). See Borden Co. v. Freeman, 256 F. Supp. 592, 601 (D.N.J.), aff'd, 369 F.2d 404 (3d Cir. 1966), cert. denied, 386 U.S. 992 (1967).

130. Section 10(e) of the APA, 5 U.S.C. $\$ 706(2)(A)(1970)$. The nature of this standard of review was outlined by Judge Wright in the National Petroleum Refiners opinion:

Any fears that an agency could successfully use rule-making power as a means of oppressive or unreasonable regulation seem exaggerated in view of courts' general practice in reviewing rules to scrutinize their statement of basis and purpose to see whether the major issues of policy pro and con raised in the submissions to the agency were given sufficient consideration. $482 \mathrm{~F} .2 \mathrm{~d}$ at 692 (emphasis added).

See Rulemaking to Deny Adjudication 1109-10.

131. FTC v. Colgate-Palmolive Co., 380 U.S. 374, 385 (1965). See FTC v. Sperry \& Hutchinson Co., 405 U.S. 233, 239-44 (1972); FTC v. Brown Shoe Co., 384 U.S. 316, 320-22 (1966). 93.

132. See notes 108-12, 121-32 supra and accompanying text. See 482 F.2d at 692-

133. See Burrus \& Teter 1120-27; Handler, Unfair Competition, 21 Iowa L. Rev. 175 (1936); Robinson 490-96; Shapiro 958-67; Weston 567-73; Note, supra note 20, at $346-47$.

134. See note 36 supra and accompanying text. 
judication . . . best accommodates the need for effective enforcement of the Commission's mandate with maximum solicitude for the interests of the regulated parties."135 Nevertheless, the court's willingness to liberally construe the language of section $6(\mathrm{~g})$ was based in great part on a recognition of the advantages inherent in the utilization of rulemaking in formulating agency policy. ${ }^{136}$ The FTC has been the subject of severe criticism for its failure to implement effectively its broad statutory mandate to prevent unfair and deceptive business practices. ${ }^{137}$ Therefore, to the extent that substantive rulemaking authority will enhance the FTC's capacity to enforce the FTCA, the $\mathrm{Na}$ tional Petroleum Refiners decision appears consistent with the broad purposes behind the Act. ${ }^{138}$ An immediate result of the National Petroleum Refiners decision may be a significant expansion of the Commission's Trade Regulation Rule program. ${ }^{139}$ Increased reliance upon Trade Regulation Rules to designate particular business practices as unfair or deceptive may eventually result in the development of a comprehensive federal code of consumer protection which would provide the nation's consumers with protection comparable to that which the federal securities laws provide to investors. ${ }^{140}$

135. 482 F.2d at 674 .

136. Id. at 681-84, 690-93. See notes 113-120 supra and accompanying text.

137. See notes 4,5 supra and accompanying text.

138. See notes $33,102,103$ supra and accompanying text. The approach of the $\mathrm{Na}$ tional Petroleum Refiners court, in sum, amounts to a willingness to permit the FTC to attempt to increase its effectiveness until it can be shown that the rights of regulated parties will necessarily be abused:

[i]n the event Congress decides that the scope of the rule-making power that we find to be implied in the [FTCA] is too broad or lacks sufficient safeguards, surely it appears im a prime position to make the required changes. $482 \mathrm{~F} .2 \mathrm{~d}$ at 697 n.40.

There is currently before Congress legislation which would clarify, but limit, the FTC's rulemaking power under section 6(g). See H.R. 20, 93d Cong., 1st Sess. § 203 (1973). A rulemaking provision which would simply have clarified section $6(\mathrm{~g})$ as conferring substantive rulemaking authority was deleted from the Senate counterpart to the House bill following the decision in National Petroleum Refiners, Wall St. Journal, Sept. 13, 1973, at 10, col. 3. It may well be that Congress will give the FTC an opportunity to make substantive rules pursuant to section $6(\mathrm{~g})$ until clarifying legislation becomes necessary. See generally FTC Substantive Rulemaking 161-70.

139. See note 7 supra and accompanying text. See FTC Substantive Rulemaking 145-47.

140. It has been said that Section 10(b) of the Securities Exchange Act of 1934, 15 U.S.C. $\$ 78 \mathrm{j}(\mathrm{b})(1970)$ and the corresponding regulation Rule 10b-5, 17 C.F.R. $\S 240.10 b-5$ (1973), have led to the development of a "federal corporation law." See W. Cary, Cases and Materials on Corporations 14 (4th ed. 1969).

Professor Davis has indicated that an increased use of rulemaking by the FTC to develop a comprehensive business code would be a desirable goal. K. DAvis, DiscreTIONARY JUSTICE 72 (1969). 